\title{
The Impact of Current Ratio, Debt to Equity Ratio, Net Profit Margin, and Total Asset Turnover towards The Profit Changes of Mining Companies Listed on Indonesia Stock Exchange Period 2016-2018 Tommy Minggus", Mohammad Wasil, I.G.A Aju Nitya Dharmani
}

Faculty of Economics and Business, Narotama University Surabaya, Indonesia, ayurai.management@gmail.com

\begin{abstract}
This study aims to determine whether CR, DER, NPM, and TATO affect to profit changes. Population in this research are mining companies listed in Indonesia Stock Exchange period 2016-2018 consisting of 48 companies. Sampling was done by purposive sampling and 15 companies were selected. The data in the study comes from the secondary data obtained through the documentation technique. Data analysis with multiple regression analysis using SPSS for Windows version 18. The results showed that there was significant influence simultaneously between CR, DER, NPM, and TATO to Profit Changes. Based on the partial test, the conclusion CR and TATO has positive and not significant effect in profit changes. DER has negative and not significant effect in profit changes. NPM has positive and significant effect in profit changes.
\end{abstract}

Keywords: Current Ratio (CR), Debt Equity Ratio (DER), Net Profit Margin (NPM), Total Asset Turnover (TATO), Profit Changes

\section{Introduction}

The business world is currently growing very rapidly demanding companies to be able to deal with all kinds of global activities. As technology advances, companies have demands to develop their business to the fullest. Indonesia is one of the countries with a wealth of natural resources and very high human resources.

There are many sectors of the company whose role to sustain the economic development of a country, one of which is the mining sector. According to Idris (2013, p. 53),"Mining is a sector that has many risks, including geological risks, related to reserve uncertainty. Technological risk, related to the uncertainty of the costs used by technology to explore materials. Government policy risks, related to changes in tax costs". The development of the GDP distribution of the mining sector in Indonesia over the past 5 years is shown in the following figure.

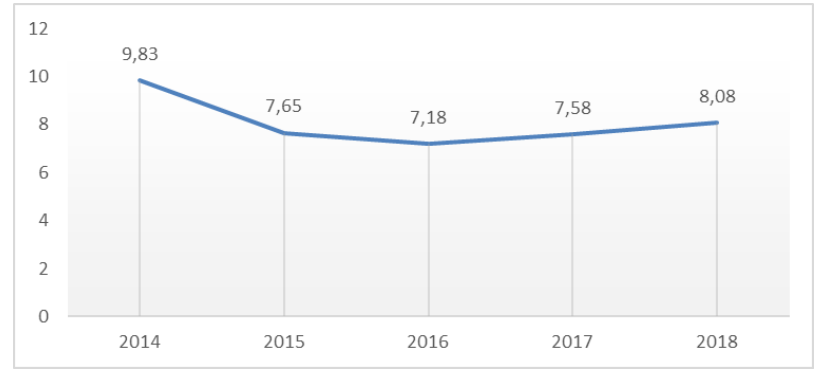

Fig. 1. Development of GDP Distribution in the Mining and Quarrying Sector Resource : BPS, 2019

\footnotetext{
* Corresponding author.

E-mail address: minggus.tommy@gmail.com (Tommy Minggus)
} 
Profit is something that illustrates the feasibility of the company for investors. Profit Changes for each period are directed to be positive. One important factor for a company is managing financial performance well, thus the company's profit will consistently increase. Financial statements are a basis of information that can be used in decision making. Decisions made require the company's evaluation results in generating profit. Then the financial statements need to be analyzed in order to provide useful information for interested parties. One of the techniques used in analyzing financial statements is to use financial ratios.

The mining sector requires a very large investment cost. For this reason, many mining companies enter the capital market to get funds from investors, which are then managed to generate profit. The Indonesia Stock Exchange (IDX) is the Indonesian capital market. The stock exchange functions as an intermediary system that brings those who need capital / funds with buyers through representatives of securities companies. In 2018 the number of companies listed on the IDX totaled 656 issuers, 48 of which were mining sector companies. The mining sector in the Indonesia Stock Exchange is one sector which is relied from various aspects.

Based on the description above, the researcher is interested in conducting research with the title"The Impact of Current Ratio, Debt to Equity Ratio, Net Profit Margin, and Total Asset Turnover Towards The Profit Changes Of Mining Companies Listed On Indonesia Stock Exchange Period 2016-2018”.

\section{Literature Review}

\subsection{Profit}

According to Subramanyam et al. (2014, p.25), states that the definition of earnings is as follows:"Earnings (net) or net income indicates the profitability of the company. Earnings reflect returns to equity holders for the period concerned, while items in the report detail how profit are earned".

Profit Change can be calculated by subtracting current period earnings with previous period earnings then divided by previous period earnings. Then the formula used to predict profit changes:

Keterangan :

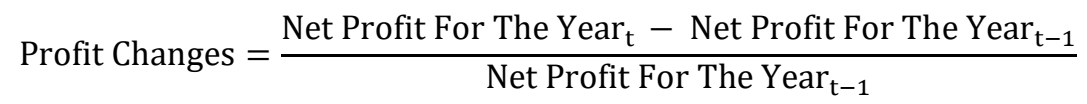

Net Profit For The Year

Net Profit For The Year $_{t-1}$
$=$ Net profit for the year

$=$ Net profit for the previous year

\subsection{Financial Report}

Financial statements are records of a company's financial information about financial conditions in an accounting period. Financial statements can be used to describe the company's performance. Information contained in the financial statements can help the parties concerned as a consideration in making decisions.

According to Fahmi (2012, p.21), the definition of financial statements is:"An information that describes the condition of a company's financial statements and further information can be used as a description of the company's financial performance".

\subsection{Financial Ratio Analysis}

Financial ratio analysis is one way to analyze financial statements that are used to assess the financial performance of a company.

Harahap (2015, p. 297): 
"This financial ratio only simplifies information that illustrates the relationship between certain posts with other posts. By this simplification we can quickly see the relationship between these posts and can compare them with other ratios thus we can get information and provide an assessment".

\subsection{Current Ratio}

One of the liquidity ratios most often used to analyze financial statements is the Current Ratio.

According to Wahyudiono (2014, p. 78), "Current ratio is most often used in measuring the level of company liquidity. The current ratio is used to measure how far the company's current assets can be used to meet its current liabilities. Current ratio is the ratio between the value of current assets and current liabilities".

\subsection{Debt To Equity Ratio}

$$
\text { Current Ratio }=\frac{\text { Current Asset }}{\text { Current Liabilities }}
$$

According to Wahyudiono (2014, p. 75),

"This ratio shows the ratio between total debt and equity. Total debt is the sum of total current liabilities and long term debt. Therefore, this Debt to Equity Ratio is often also called the Total Debt to Equity Ratio."

$$
\text { DER }=\frac{\text { Current Liabilities }}{\text { Equity }}
$$

\subsection{Net Profit Margin}

This ratio shows how much percentage of net income earned from each sale. The higher this ratio the better because it is considered the company's ability to earn high profit.

$$
\text { Net Profit Margin }=\frac{\text { Net Revenue }}{\text { Net Sales }}
$$

\subsection{Total Asset Turnover}

According to Harahap (2015, p. 304), 'This ratio shows the total asset turnover measured by sales volume in other words how far the ability of all assets to create sales. The higher this ratio the better."

\section{Theoretical Framework}

$$
\text { Total Asset Turnover }=\frac{\text { Net Sales }}{\text { Total Asset }}
$$

\subsection{The Impact of Current Ratio towards Profit Changes}

Current ratio is the ratio used to measure a company's ability to meet its short-term debt by comparing current assets with current liabilities. The higher current ratio means the company's ability to meet its short-term debt is greater. The effect of Current Ratio on profit changes is if the company is able to cover the current liabilities well, then the company can manage the current assets well, thus it can have an effect in profitability. From this description it can be seen that the current ratio has a positive effect on changes in profit, which means that the higher the level of the company's current ratio, the rate of profit changes at the company will also be higher. The research result Yetty et al. (2018, p. 50), states that the current ratio has a significant effect on profit changes, which means that the company is able to meet short-term debt corporate, the value of the current ratio found in the company can encourage profit growth. 


\subsection{The Impact of Debt to Equity Ratio towards Profit Changes}

Debt Equity Ratio (DER) is used to assess the company's debt and equity, a high DER shows that there is no efficiency in the company's performance in optimizing its own capital to guarantee all company debt. According to Sudana, (2011 , p. 20 )" The greater the DER shows the greater the proportion of the use of debt in financing investments in assets which also means increased financial risk and vice versa". The smaller capital composition shows that most of the company's funding comes from debt. From this description it can be seen that the DER has a negative effect on profit changes.

\subsection{The Impact of Net Profit Margin towards Profit Changes}

Net Profit Margin (NPM) is the ratio of net income to total revenue, a high NPM indicates the company's high ability to generate net profit on certain sales. The higher NPM, make company's profit changes higher. According to Werner ( 2013 , p. 64 ) ,"an increased NPM will increase the company's profit growth". This is caused by the company being able to convert the sales into net profit by managing the operating costs efficiently. From this description it can be seen that NPM has a positive influence on profit changes.

\subsection{The Impact of Total Asset Turnover towards Profit Changes}

Total Assets Turnover (TATO) is a ratio used to measure the company's ability to generate company sales is based on the total assets. The higher turnover rate the more effective the company makes use of the assets. If the company is able to manage the assets well, the company's ability to generate profit also will be good. From the description above it can be concluded that the TATO ratio has a positive effect on profit changes. The research result Sari et al. ( 2017, p. 63 ), states that TATO has a significant influence on profit growth. The faster the rate of turnover of the assets, the net profit generated will increase because the company already can use the assets to increase sales that affect revenue. Based on the description above, a research model can be made as shown in Figure 2.

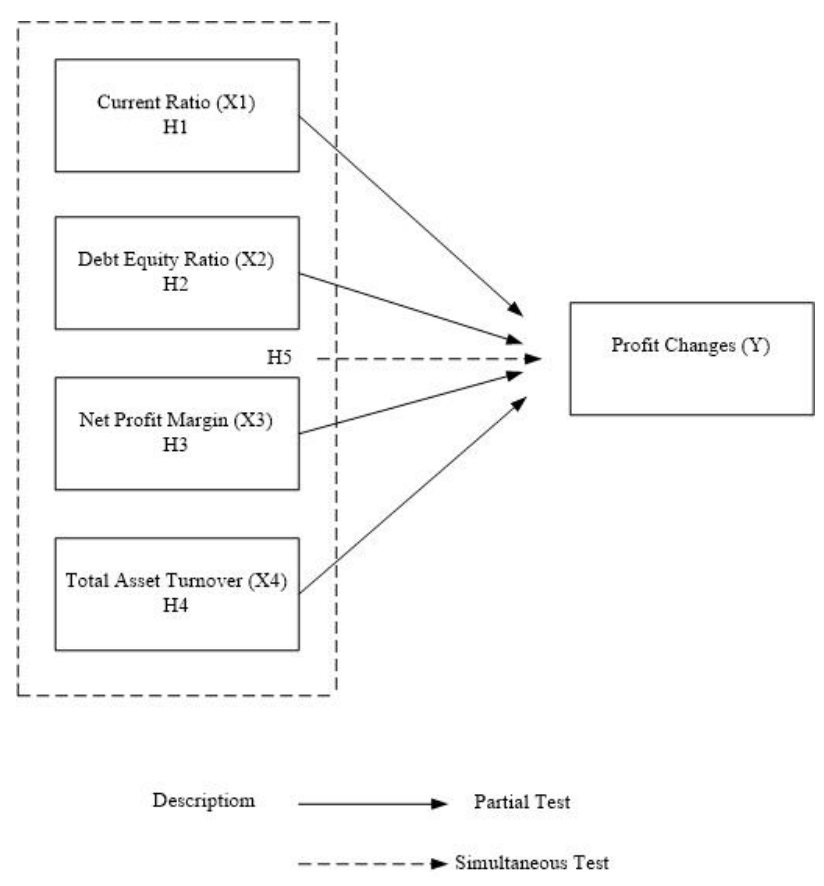

Fig. 2. Theoretical Framework 


\subsection{Hypotheses}

H1 : Current Ratio has a significant positive effect on Profit Changes.

H2 : Debt to Equity Ratio has a significant negative effect on Profit Changes.

H3 : Net Profit Margin has a significant positive effect on Profit Changes.

H4 : Total Asset Turnover has a significant positive effect on Profit Changes.

H5 : Current Ratio, Debt Equity Ratio, Net Profit Margin, and Total Asset Turnover has a significant positive effect on Profit Changes.

\section{Research Methods}

\subsection{Types of research}

In this study, researchers used a quantitative approach. Quantitative research is a form of numbers to test a hypothesis. By using this approach, the significance of the relationship between the variables studied will be obtained.

\subsection{Research Object}

The object in this study is the financial ratios of mining companies listed on the Indonesia Stock Exchange which include current ratio, debt to equity ratio, net profit margin, total asset turnover, and profit change. The data period used in this study was 3 years from 2016 to 2018 .

\subsection{Population and Sample}

In this study, the population used is mining companies listed on the Indonesia Stock Exchange for the period of 2016 to 2018. The sampling technique used in this study was purposive sampling, sampling technique is the technique used to take samples. The selection of purposive sampling method aims to obtain the required data, while the criteria for taking this sample are:

1. Mining companies listed on the Indonesia Stock Exchange in the period 2016-2018.

2. Mining companies that IPO before 2016.

3. Mining companies report successively financial statements during the research period.

4. Mining companies that have made profit for 4 consecutive years are 2015-2018.

Based on the sampling results obtained by mining companies amounted to 48 companies and those who meet the sampling criteria amounted to 15 companies. The analysis will be carried out over 3 periods, which is the period 2016-2018 thus the data from the sample amounted to $15 \times 3=45$.

\subsection{Data Type}

The type of data used in this research is quantitative. The type of data needed is the financial statements of mining companies in 2016-2018 obtained from the official website of the Indonesia Stock Exchange: https://www.idx.co.id/company-noted/report-finance-and-tahunan/ (downloaded, 11-10-2019 18.22 GMT+7) .

\subsection{Data Source}

This study uses secondary data, which is financial statements such as balance sheets and income statement of mining sector companies listed on the Stock Exchange during the period 2016-2018. The source of the data was obtained from the company's financial statements published on the official website of the Indonesia Stock Exchange (IDX), which is https://www.idx.co.id/company-noted/report-finance-and-tahunan/ (downloaded, 11-10 -2019 18.22 GMT+7). 


\subsection{Data Analysis Technique}

In this study the data analysis technique uses multiple linear regression, which is an analysis technique to determine the effect of the independent variable with the dependent variable that shows a one-way relationship. The models in this study are:

$$
\mathrm{Y}=\alpha+\beta 1 X 1+\beta 2 X 2+\beta 3 X 3+\beta 4 X 4+e
$$

Keterangan :

$$
\begin{array}{ll}
\mathrm{Y} & =\text { Profit Changes } \\
\alpha & =\text { Constanta } \\
\beta 1-\beta 4 & =\text { Coefisien Regression } \\
\mathrm{X} 1 & =\text { Current Ratio } \\
\mathrm{X} 2 & =\text { Debt Equity Ratio } \\
\mathrm{X} 3 & =\text { Net Profit Margin } \\
\mathrm{X} 4 & =\text { Total Asset Turmover } \\
\mathrm{e} & =\text { Standart error }
\end{array}
$$

\section{Result and Discussion}

The classic assumption test is a requirement that must be fulfilled in multiple linear regression analysis. This test aims to provide certainty that the regression equation obtained has accuracy in estimation, unbiased, and consistent.

\subsection{Normality Test}

This test is used to determine the data contained in each variable is normally distributed or not. Normality Test Results can be seen in Table 1 .

Table 1. Uji Kolmogorov Smirnov

\begin{tabular}{ccc}
\hline $\begin{array}{c}\text { One-Sample } \\
\text { Kolmogorov-Smirnov-Test }\end{array}$ & Unstandardized Residual & Description \\
\hline Asymp. Sig. (2-tailed) & 0.676 & Normal \\
\hline
\end{tabular}

Based on the Kolmogorov Smirnov test it can be seen that the data in this study are normally distributed. Seen on Asymp. Sig ( 2 tailed) of 0.676 indicates a significant value greater than 0.05 which means the data is normally distributed.

\subsection{Multicollinearity Test}

Multicollinearity test is used to find out whether in the regression model there is a variance in variance from the residuals of one observation to another . Multicollinearity Test Results can be seen in Table 2.

Table 2. Uji Multikolonieritas

\begin{tabular}{ccc}
\hline \multirow{2}{*}{ Variabel } & \multicolumn{2}{c}{ Collinearity Statistics } \\
\cline { 2 - 3 } & Tolerance & VIF \\
\hline Current Ratio & 0.671 & 1.491 \\
Debt Equity Ratio & 0.571 & 1.750 \\
Net Profit Margin & 0.777 & 1.287 \\
Total Asset Turnover & 0.731 & 1.369 \\
\hline
\end{tabular}


In table 2, it can be seen that the data meet the multicollinearity test requirements because the tolerance value of each variable is $\leq 0.10$ and the VIF value of each variable is $\geq 10$ which means that the variable does not occur multicollinearity.

\subsection{Autocorrelation Test}

Autocorrelation test is used by researchers to test whether in the linear regression model there is a correlation between the interruption error in the $t$ period and the confounding error in the $t$ (previous) period. in this study, researchers used the Durbin Watson (DW test) approach . The results of the Durbin Watson test can be seen in Table 3.

Table 3. Autocorrelation Test

\begin{tabular}{cc}
\hline Durbin-Watson & Description \\
\hline 2.101 & There is no autocorrelation \\
\hline
\end{tabular}

To find out the existence of autocorrelation or can not be known by the DW-Test with the terms $d u<d<4-d U$, a good regression model is one that does not have autocorrelation. The test results using the Durbin Watson table can be seen in Table 4.

Table 4. Uji Durbin Watson

\begin{tabular}{ccccc}
\hline $\mathrm{D}$ & $\mathrm{dL}$ & $\mathrm{dU}$ & $4-\mathrm{dL}$ & $4-\mathrm{dU}$ \\
\hline 2.101 & 1.335 & 1.720 & 2.665 & 2.280 \\
\hline
\end{tabular}

Based on the DW table, the DW numbers are located between $\mathrm{dU}$ and $(4-\mathrm{dU}), 1,720<2,101<2,280$. Thus can be concluded that the regression model in this study does not have autocorrelation.

\subsection{Heterokedasticity Test}

Heterokedasticity test used to find out whether the regression model occurred inequality variants of residuals of the observations to other observations . Heteroscedasticity test can be seen in Figure 3.

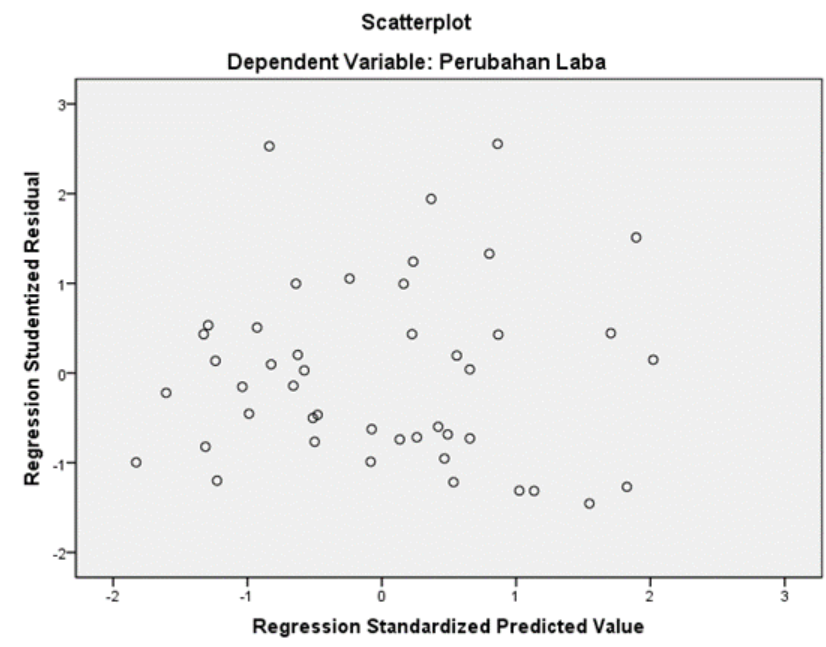

Fig. 3. Heterokedasticity Test

In Fig. 3, it can be seen that the points spread randomly and spread both above and below 0 on the $\mathrm{Y}$ axis, and there are no specific patterns, this concludes that there is no heterokedasticity. 


\subsection{Multiple Linear Regression Test}

The results of multiple linear regression analysis in this study can be seen in Table 5 .

Table 5. Multiple Linear Regression Test

\begin{tabular}{cc}
\hline Model & Unstandardized Coefficients \\
\hline (Constant) & -0.269 \\
CR & 0.007 \\
DER & -0.078 \\
NPM & 4.657 \\
TATO & 0.172 \\
\hline
\end{tabular}

Based on the analysis results in table 8, the linear regression equation is obtained as follows:

$$
\mathrm{Y}=-0,269+0,007 X 1-0,078 X 2+4,657 X 3+0,172 X 4+e
$$

\subsection{Coefficient of Determination $\boldsymbol{R}^{2}$}

The coefficient of determination test aims to find out how much the model's ability to explain the variation of the dependent variable. Test results in this study can be seen in table 6 .

Table 6. Uji Koefisien Determinasi $\boldsymbol{R}^{2}$

\begin{tabular}{cc}
\hline Adjusted R Square & Description \\
\hline 0.147 & Weak \\
\hline
\end{tabular}

The test results of the coefficient of determination $\left(R^{2}\right)$ indicate that the Adjusted $\mathrm{R}$ Square value of 0.147 or $14.7 \%$. This means that the rate of profit change that can be explained by independent variables (CR, DER, NPM, and TATO) is $14.7 \%$, while the remaining $85.3 \%$ is influenced by other variables not examined.

\subsection{F Test (Simultaneous)}

Simultaneous hypothesis testing aims to determine the effect of CR, DER, NPM, and TATO independent variables simultaneously (together) on the dependent variable which is profit change. The $\mathrm{f}$ test results in this study can be seen in table 7.

Table 7. F Test

\begin{tabular}{ccc}
\hline F & Sig. & Description \\
\hline 2.900 & 0.034 & Significant \\
\hline
\end{tabular}

$\mathrm{F}$ test results show that $\mathrm{F}$ count $(2,900)$ and sig. (0.034), when compared to $\mathrm{F}$ table $(2.61)$, then $\mathrm{F}$ count $>\mathrm{F}$ table and sig. $<\alpha 0.05$, thus it can be concluded that the model is significant.

\subsection{Ttest (partial)}

Partial hypothesis test aims to determine the effect of CR, DER, NPM, and TATO independent variables partially (individually) on the dependent variable which is profit changes. T test results in this study can be seen in Table 8 .

$\mathrm{T}$ test results on the variable CR (X1), the regression coefficient of 0.007 (positive), with $\mathrm{t}_{\text {count }}(0.045)$ and sig (0.964), when compared with $t_{\text {table }}(1.683)$, then $t_{\text {count }}<t_{\text {table }}$ and sig. $>\alpha(0.05)$, assuming other variables are considered constant, it can be concluded that the Current Ratio has a positive but not significant effect on profit changes. 
$\mathrm{T}$ test results on the DER variable (X2), the regression coefficient of -0.078 (negative), with $t_{\text {count }}(-0.254)$ and sig (0.801), when compared with $t_{\text {table }}(-1.683)$, then $t_{\text {count }}>t_{\text {table }}$ and sig. $>\alpha(0.05)$, assuming other variables are considered constant, it can be concluded that the Debt Equity Ratio has a negative but not significant effect on profit changes.

Table 8. T Test

\begin{tabular}{ccccc}
\hline Model & $\mathrm{B}$ & $\mathrm{t}$ & Sig. & Description \\
\hline (Constant) & -0.269 & -0.461 & 0.647 & Not Significant \\
CR & 0.007 & 0.045 & 0.964 & Not Significant \\
DER & -0.078 & -0.254 & 0.801 & Significant \\
NPM & 4.657 & 2.524 & 0.016 & Not Significant \\
TATO & 0.172 & 0.636 & 0.529 & \\
\hline
\end{tabular}

T test results on the variable NPM (X3), the regression coefficient of 4.657 (positive), with $t_{\text {count }}(2.524)$ and sig (0.016), when compared with $t_{\text {table }}(1.683)$, then $t_{\text {count }}>t_{\text {table }}$ and sig. $<\alpha(0.05)$, assuming other variables are considered constant, it can be concluded that Net Profit Margin has a significant positive effect on profit changes.

$\mathrm{T}$ test results on the TATO variable (X4), the regression coefficient of 0.172 (positive), with $\mathrm{t}_{\text {count }}(0.636)$ and sig (0.529), when compared with $t_{\text {table }}(1.683)$, then $t_{\text {count }}<t_{\text {table }}$ and sig. $>\alpha(0.05)$, assuming other variables are considered constant, it can be concluded that $\mathrm{T}$ otal $\mathrm{A}$ sset $\mathrm{T}$ turnover has a positive but not significant effect on profit changes.

\section{Conclusion}

This study aims to test and prove the effect of Current Ratio, Debt Equity Ratio, Net Profit Margin, and Total Asset Turnover on profit changes of mining companies on the Stock Exchange 2016-2018, based on the results of multiple linear regression tests, the conclusions:

(1) The results of partial test indicate that the Current Ratio (X1) has no significant positive effect on Profit Changes (Y). This means that the high Current Ratio will not be followed by an increase on Profit Changes in mining companies.

(2) The results of partial testing indicate that the Debt Equity Ratio (X2) has no significant negative effect on Profit Changes (Y). This means that the low Debt Equity Ratio will not be followed by an increase on Profit Changes in mining companies.

(3) The partial test results show that Net Profit Margin (X3) has a significant positive effect on Profit Changes (Y). This means that the high Net Profit Margin will be followed by an increase on Profit Changes in mining companies.

(4) Partial test results indicate that the Total Asset Turnover (X4) has a significant positive effect on Profit Changes (Y). Partial test results indicate that the Total Asset Turnover (X4) has a significant positive effect on Profit Changes (Y). This means that the high Total Asset Turnover will not be followed by an increase on Profit Changes in mining companies.

For prospective investors, before investing the capital is expected to pay more attention to the ratios or other factors both from within and outside the mining company relating to profit changes in order to make the right decision to invest, because the profit obtained by the company will be related to the amount of return in the form dividends on investments to be made.

For further researchers, the influence of the four variables is still very small, evidenced by the coefficient of determination, Adjusted R Square of 0.147 or $14.7 \%$. This means that the rate of profit changes that can be explained by independent variables (CR, DER, NPM, and TATO) is $14.7 \%$, while the remaining $85.3 \%$ is influenced by other variables not examined. For time series researchers with the same theme, it is better to increase the number of independent variables so that the research results can be even better. 


\section{References}

Bursa Efek Indonesia. Laporan Keuangan dan Tahunan. Retrieved from https://www.idx.co.id/perusahaantercatat/laporan-keuangan-dan-tahunan/. Downloaded, 11-10-2019 18.22 WIB.

Harahap, \& Syafri, S. (2015). Analisis Kritis Atas Laporan Keuangan. Jakarta: Rajawali Pers.

Idris, M. F. (2013). Pembangunan Melalui Sektor Pertambangan di Indonesia: Sebuah Tinjauan Etis. Jurnal Ilmu Pengetahuan Dan Teknologi, 53.

Irham, F. (2012). Analisis Laporan Keuangan. Cetakan Ke-2. Bandung: Alfabeta.

Muhadi, W. R. (2013). Analisis Laporan Keuangan, Proyeksi dan Valuasi Saham. Jakarta: Salemba Empat.

Sari, L., \& Lestari, W. (2017). Pengaruh Working Capital To Total Assets, Debt To Equity Ratio, Total Asset Turnover Dan Net Profit Margin Terhadap Pertumbuhan Laba Pada PT Bukit Asam periode 2009-2014. Jurnal Riset Akuntansi Dan Manjemen, 63.

Subramanyam, K. ., \& Wild, J. J. (2014). Analisis Laporan Keuangan. Jakarta: Salemba Empat.

Sudana, I. M. (2011). Manajemen Keuangan Perusahaan. Jakarta: Erlangga.

Wahyudiono, B. (2014). Mudah Membaca Laporan Keuangan. Jakarta: Raih Asa Sukses.

Yetty, N. M., Asih, P., \& Apriyanto, G. (2018). Rasio Keuangan Dalam Memprediksi Pertumbuhan Laba Pada. Jurnal Riset Inspirasi Manajemen Dan Kewirausahaan, 50. 